\title{
The collision of Empires as seen from Istanbul: the border of British-controlled Egypt and Ottoman Palestine as reflected in Ottoman maps
}

\author{
Yuval Ben-Bassat ${ }^{\mathrm{a}, *}$ and Yossi Ben-Artzi ${ }^{\mathrm{b}}$ \\ ${ }^{a}$ Department of Middle Eastern History, Eshkol Tower, 1507, University of Haifa, 199 Aba Khoushy Road, 3498838, Haifa, Israel \\ ${ }^{\mathrm{b}}$ Department of Israel Studies, Eshkol Tower, 1418, University of Haifa, 199 Aba Khoushy Road, 3498838, Haifa, Israel
}

\begin{abstract}
This article analyses the historical and cartographical understanding of the creation of the border between Egypt and Ottoman Palestine - Israel's current southern border - by examining Ottoman maps from the period between the mid nineteenth century and World War I. These maps deal with different stages of the border's definition and demarcation, and shed light on the Ottoman view of the region and its borders, which differs considerably from the more widely known British perspective. Most of these maps were not produced to deal directly with the issue of the border, but when embedded within the broader Ottoman cartographic and geopolitical framework, provide crucial information which allows us to trace the process of border definition. (c) 2015 Elsevier Ltd. All rights reserved.
\end{abstract}

Keywords: Ottoman Empire; Egypt; Palestine; Borders; Cartography

The aim of this article is to amend the historical and cartographic understanding of the setting of the border between Britishcontrolled Egypt and Ottoman Palestine in 1906, which later became the border between Israel and Egypt. It does so by presenting eight Ottoman maps recently located at the Turkish Prime Minister's Ottoman Archive in Istanbul (the Başbakanllk Osmanl Arşivi, henceforth BOA). These maps, some of which were official and others not, help trace the process of defining this border and shed light on the Ottoman viewpoint on its creation. This viewpoint has largely been ignored by researchers and is much less wellknown than the British perspective. The maps in the set discussed here were mainly produced prior to 1906 and deal with the internal administrative borders between the Ottoman provinces of Egypt, the Hijjaz and Syria (the southern part of which became the Province of Jerusalem in 1872). These internal administrative borders later influenced the creation of the border between Britishheld Egypt and Palestine under Ottoman rule.

The Ottoman maps presented in this article confirm that this Empire had relatively few reliable maps on which to base its geopolitical and territorial claims as it came under increasing pressure from the European colonial powers throughout the nineteenth and early twentieth centuries. The maps, moreover, reveal differences in the 'cartographic cultures' between the Europeans, in this case the British who ruled Egypt, and the Ottomans. Modern Ottoman cartography was virtually non-existent before the turn of the twentieth century, which helps explain the state of Ottoman cartography in the Sinai desert before that time. Unlike efforts by Western cartographers at the time to produce professionally accurate maps reflecting the physical characteristics of a given territory as well as human activity there, Ottoman cartographers were for the most part mainly interested in producing schematic maps that only represented certain features such as prominent natural characteristics, major settlement localities, infrastructure, roads and railroads, and administrative borders. The first major surveying project in the Empire that included triangulations and careful modern map making took place only in the 1910s. ${ }^{1}$ At that time the Young Turk regime, which took over the Empire in 1908, commissioned the Ottoman army's mapping department to systematically map the Empire's territories, starting with its core regions.

\footnotetext{
* Corresponding author.

E-mail addresses: yuval@research.haifa.ac.il, yossib@univ.haifa.ac.il.

1 See Harita Genel Müdürlügü, Haritacı Mehmet Şevki Paşa ve Türk Haritacılk Tarihi [Mehmet Sevki Pasha the Cartographer and History of Turkish Cartography], Ankara 1980.
} 
Prior to this date, Ottoman maps were not drawn by professional cartographers using modern mapping techniques. These maps could not have been used for definitively marking boundaries as they were too general and imprecise. ${ }^{2}$ Nonetheless they still represent Ottoman approaches to the issue of the Empire's borders - as vague as this concept was given that the Empire's borders were not themselves precisely fixed. Thus, even though some of the maps discussed here were obviously not official documents, they reveal a great deal about the Ottoman perception of political space. Moreover, during the rule of Sultan Abdülhamid II (r. 1876-1909), maps were used frequently by the Ottomans for ideological purposes. During this sultan's rule, maps were produced for the first time to show the borders of the whole Empire - which extended over parts of three continents - to be used in classrooms and elsewhere. ${ }^{3}$ These official maps often ignored changes in the actual borders of the Empire and continued to treat territories lost in previous years, including the Sinai desert, as though they were still under Ottoman rule. ${ }^{4}$ This ideological choice was part of an effort to create a shared national agenda among Ottoman subjects at a time when the Empire was rapidly losing many of its territories, and to project an image of unity under Ottoman rule.

After 1882, when the British occupied Egypt, and up to WWI, the importance of the border region between Ottoman Palestine and Sinai increased considerably. Not surprisingly, as a result, at the turn of the century there was extensive Ottoman investment in the southern part of Palestine (which was included in the District of Jerusalem), whose strategic importance vis-à-vis the frontier with Sinai was growing. This included the establishment of Beersheba in the early twentieth century as an administrative centre around which the Bedouin tribes were to be settled; the founding of the border town of 'Awja al-Hafir and the new administrative sub-district of al-Hafir near the border between the Negev and Sinai deserts; investment in infrastructure (telegraph lines, bridges, roads and railroads); and a reorganization of the region's administrative units along with efforts to register tribal land.

Despite these strategic considerations, and actual steps taken on the ground, the Ottoman Empire was ill-prepared for the tough negotiations with the British in 1906 over the demarcation of the $230 \mathrm{~km}$-long border between Sinai and Palestine. They had no adequate cartographic information on this region, and during the negotiations they had to rely on British maps to which annotations in Ottoman Turkish were added. Although it is speculative to assume that better maps would have helped the Ottomans withstand British pressure, at least tactically it could perhaps have improved their position when delineating the final border by insisting on the inclusion of important water sources and strategic points near the border within their territory. ${ }^{5}$

\section{Politics, maps and the Sinai-Palestine border}

The history of the border between Ottoman Palestine and the Sinai Peninsula has attracted the attention of several previous researchers, particularly since it became an international problem during the peace negotiations between Israel and Egypt at the end of the 1970s. ${ }^{6}$ At that time, these two states were engaged in a tense standoff over the demarcation of several specific points along their future border, most notably the shoreline of Taba on the Red Sea, some $12 \mathrm{~km}$ south of the Israeli port town of Eilat, a dispute which was eventually resolved by international arbitration between the two sides in $1986 .{ }^{7}$

Historically, Ras Taba shore was the southernmost point held by the Ottomans on the Red Sea shores of Sinai after their 1906 agreement with Britain to mark the border between Egypt and Palestine, which was reached under heavy British pressure and following skirmishes between British/Egyptian and Ottoman forces earlier that year. For the Ottomans it was a key strategic point that they insisted on maintaining sovereignty over given its vantage point close to the head of the Gulf of 'Aqaba and their interests in keeping 'Aqaba and the entire head of the Gulf beyond the reach of British cannons. The town of 'Aqaba was not only an important strategic garrison but was also located on a historical pilgrimage route from Egypt to the holy Islamic cities in the Hijjaz. The British, for their part, wanted to keep the Ottomans as far as possible from the Suez Canal, while leaving no doubt about British sovereignty over the Sinai desert, and eliminating the last Ottoman presence on the western shores of the Gulf of 'Aqaba (see Fig. 1).

By contrast, the Ottoman approach to Sinai was based on the line defined in the 1841 Inheritance Firman granted by Abdülmecid (r. 1839-1861), the Ottoman sultan at the time, to the governor of Egypt, Muhammad 'Ali (r. 1805-1848). In the 1830s, Egyptian troops led by Muhammad 'Ali's son Ibrahim had stormed the Levant and reached central Anatolia, thus threatening the very existence of the Ottoman Empire. In 1840-1841, following European and above all British intervention, the crisis was resolved and Muhammad 'Ali's army withdrew back to Egypt. In return, on February 13, 1841 (and again on June 1 of the same year) he was granted an imperial Ottoman decree (the Inheritance Firman) which authorized him and his descendants to rule Egypt on behalf of the Ottomans.

As of 1892, however, Evelin Bering, the British Consul in Egypt who later became Lord Cromer, made efforts to discredit the fact that from 1841 on, when the Inheritance Firman was issued, the eastern border of Egypt stretched from Rafah on the Mediterranean shore directly to Suez, leaving almost all of Sinai in Ottoman hands. Instead he promoted a line which went from 'Aqaba at the head of the Gulf of 'Aqaba in the Red Sea to Rafah and worked to gain the British full control over Sinai (see Fig. 1).

The Red Sea shores of the Hijjaz up to 'Aqaba were of lesser importance to the British at that time. Direct steamboats carrying pilgrims from the port town of Suez to Jedda had minimized the need to keep fortresses along the Red Sea in this region to protect the pilgrimage land routes. Thus, the fortresses built there by Egyptian forces in the preceding decades were evacuated in the 1890s, and the region, including 'Aqaba, was once more subordinated to the Ottoman administration in the Hijjaz. Nevertheless, the Sinai

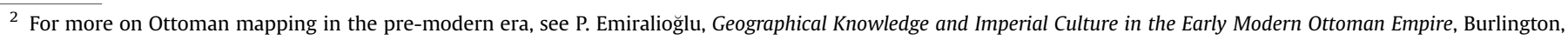
VT 2014.

3 B. Fortna, Imperial Classroom: Islam, Education and the State in Late Ottoman Empire, Oxford 2002, $186-191$.

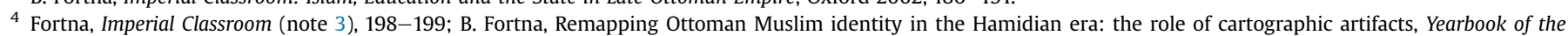

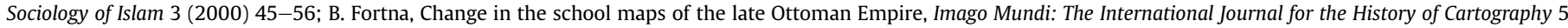
(2004) 29-30.

5 See M. Brawer, Israel's Boundaries, Tel-Aviv 1988, 74.

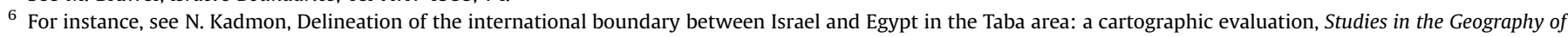

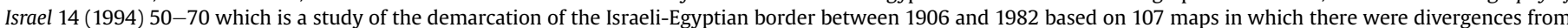

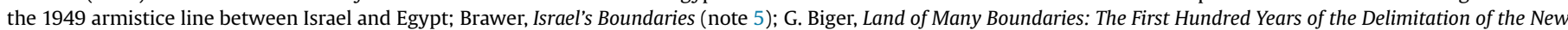

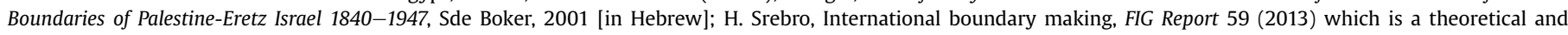

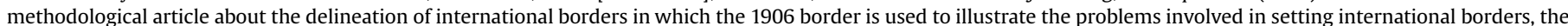
technical skills required, how to measure points along the border and how to mark them on the ground.

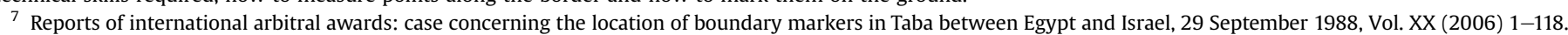




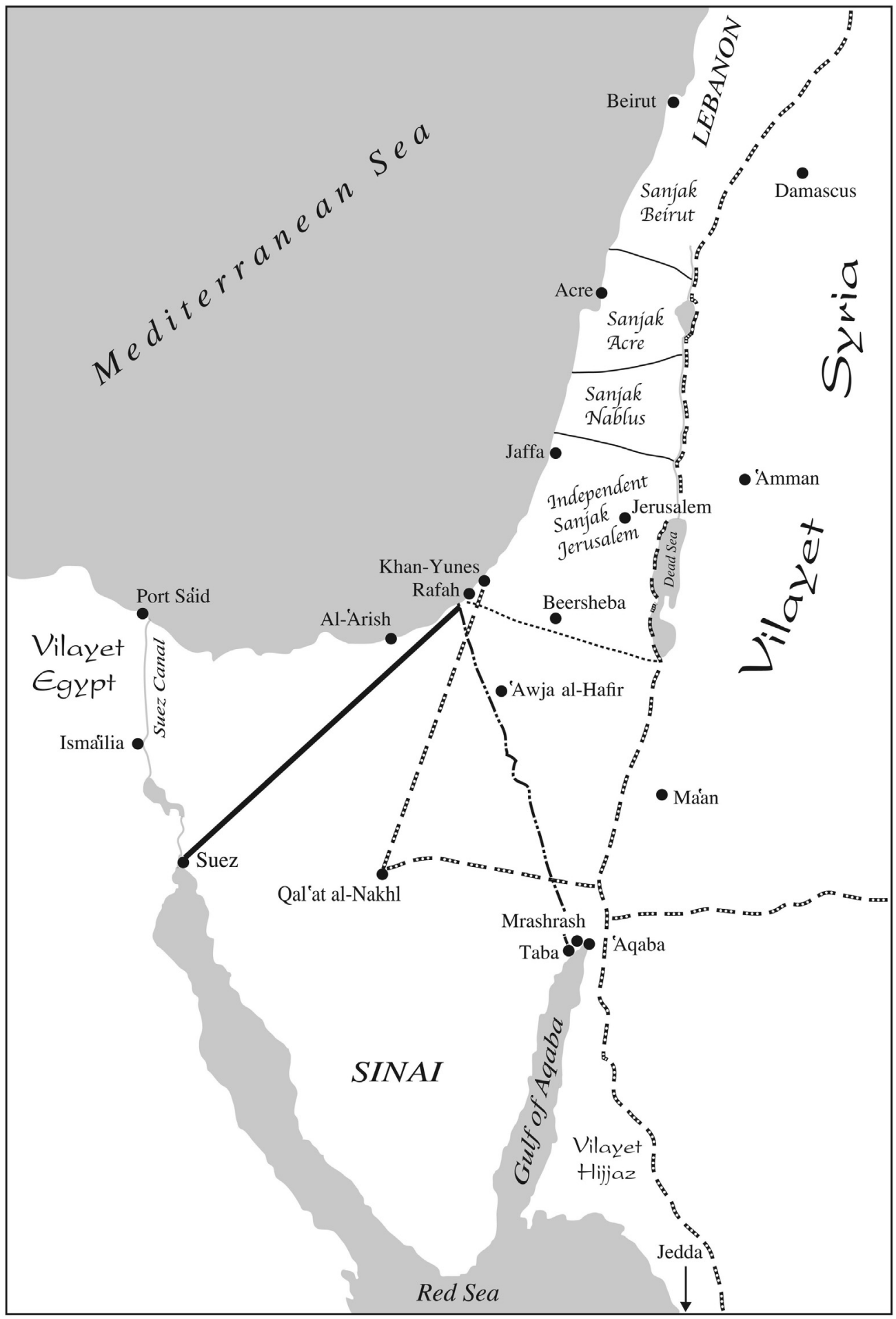

Inheritance Firman Line (1841)

$m \mathbf{m} m \mathbf{m} m \mathbf{m} \quad$ Vilayet [province] administrative lines

Sanjak[district] administrative lines

Border line of 1906 [and current International Border Egypt-Israel]

British (Bramly) initial suggested line 1906

Fig. 1. Administrative lines and settlements ca. 1900 
Peninsula in general, and Qala't al-Nakhl in its centre on the land road from Suez to 'Aqaba, in particular, became vital for the protection of the Suez Canal. These strategic considerations increased in importance after 1899 when the Ottomans founded the town of Beersheba in southern Palestine, and commenced operations to strengthen their sovereignty among the Bedouin tribes in the region. In addition, in 1904 the Hijjaz railway stretching from Damascus to Medina reached Ma'an in southern Transjordan, not very far from 'Aqaba. The British authorities in Egypt observed these developments with much concern. Eventually, the Ottoman initiatives as well as the increasing importance of the canal led to a clash between the British and the Ottomans in 1906 over the issue of the border of Sinai with Palestine and resulted in a stern British demand to draw the border on a straight line from Rafah to the Gulf of 'Aqaba. ${ }^{8}$

The contemporary maps of the Sinai-Palestine border that researchers have used are, for the most part, at a very small scale which makes it impossible to examine details or identify important geographical data. ${ }^{9}$ Even more crucially, most research on the setting of this border has been based on Western, and primarily British, sources. For instance, several major studies deal with a detailed survey conducted by Jennings Bramly, the governor (from 1904) of the area under Egyptian control in the Sinai Peninsula (the triangle between Suez, al-'Arish and Port Sa'id, see Fig. 1). Bramly surveyed eastern Sinai to map the spread of Bedouin tribes in this region, water sources and other points of interest. ${ }^{10}$ His work was part of the British preparations to enhance their control of the Sinai desert, which they saw as a critical buffer zone between the Suez Canal and the Ottoman Empire to the north. The British efforts reached their peak in 1906 when the new border, favourable to British interests, was forced on the Ottomans. There are also studies based on Bramly's diaries in which he recorded the events leading to 1906 , as well as later interviews with him. ${ }^{11}$

By contrast, there are very few studies of the Sinai-Palestine border based on Ottoman sources. One such source that has been cited in several studies is a booklet called The Aqaba Question ('Aqaba meselesi), published by Rushdi Pasha, the Ottoman officer who headed the garrison in 'Aqaba and played a major role in the skirmishes with the British in the region in 1906. Rushdi Pasha's booklet was published in Istanbul in 1908, some two years after the events took place, and includes two maps. ${ }^{12}$ The first is titled 'A map of the Sinai Peninsula', in which the line of the Inheritance Firman from 1841 is marked as going from Suez to some point on the coastal plain of the Mediterranean Sea close to modern-day Rafah. This obviously places the Sinai out of Muhammad 'Ali's reach, a point we discuss in detail below.

The 1906 line from Rafah to Taba, which eventually became the basis for the border between Egypt and Palestine, is also marked on Rushdi Pasha's map, although in one region it goes deep into the
Sinai in an unusual way, thus leaving more territory in Ottoman hands than was eventually agreed upon by both sides. Another interesting line on this map goes from Rafah to the southern part of the Dead Sea. This is the line suggested by Jennings Bramly at the beginning of the negotiations between the British and the Ottomans, when he was sent to Mrashash (more commonly known as Umm Rashrash, today Eilat). Such a line, if adopted, would have given the British control not only of the Sinai desert but also of large parts of Palestine (see Fig. 1).

The second map in Rushdi Pasha's booklet is called "Aqaba and its Environs', and is at a scale of 1:100,000. It shows the head of the Gulf of 'Aqaba and the border region between Egypt and Palestine which Rushdi Pasha calls 'the line of separation'. Notably, the line this officer marked does not coincide in several places with the border eventually agreed upon in the negotiations between the British and the Ottomans in 1906.

Another Ottoman source used by researchers is a map of the Inheritance Firman which was first published by the Israeli geographer Gideon Biger. ${ }^{13}$ The firman was accompanied by a general map delineating the borders of the newly created Ottoman Egypt under the House of Muhammad 'Ali, which was sent to Egypt but was then lost for many years. ${ }^{14}$ In the text of the firman itself, however, there is no written description of the borders of the Province of Egypt. The Egyptian authorities apparently knew where the borders of their province were situated, but did not possess the original map. A map depicting the official borders of Egypt according to the 1841 Inheritance Firman was only published by the British in 1926, after a border crisis between Egypt and Libya prompted by the Italian occupation. The British ambassador to Turkey is said to have found the original map in the Turkish Prime Minister's Archive in Istanbul. The Turkish authorities then prepared a reliable copy for the British which has Ottoman notes in the margins. Biger found this copy in the British archives. ${ }^{15}$

The discussion above shows that the strategic importance of the Sinai region grew tremendously at the end of the nineteenth century. Located between British-controlled Egypt and Ottoman Palestine, this border region became the focus of British interests and they made concerted efforts to take it from the Ottomans. Research thus far on the border that resulted has almost completely been based on British sources. Rarely have Ottoman sources been used to explain the conflict and as a result the Ottoman conception of this border has been ignored. Based on Ottoman maps, our research demonstrates how the Ottomans perceived the border dispute and the border region in ways that significantly differed from the British. In particular, the Ottomans continued to base their considerations on the 1841 Inheritance Firman, which leftmost of Sinai under their sovereignty. They thus perceived the 1906 line as a line that was forced upon them and found it hard to accept as the

\footnotetext{
8 Biger, Land of Many Boundaries (note 6), 35-39.

${ }^{9}$ For instance, see International boundary study Israel-Egypt (United Arab Republic) boundary, US Department of State 46 (1965) which includes a 1:125,000 scale map

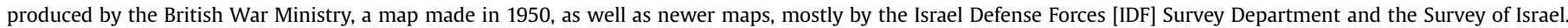

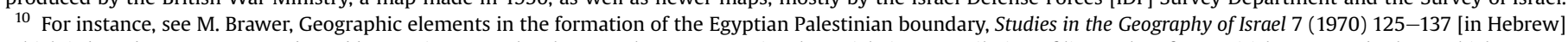

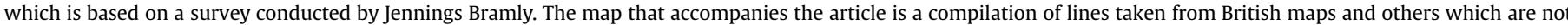

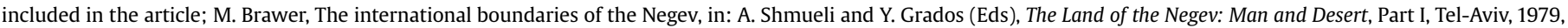
368-379 [in Hebrew].

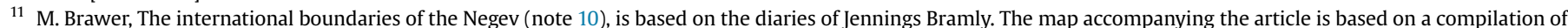

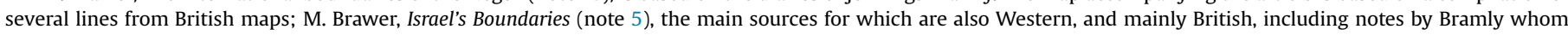

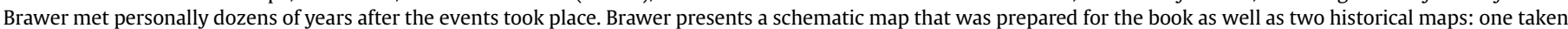

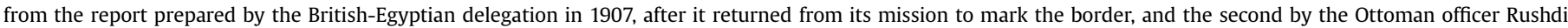
Pasha taken from his documentation.

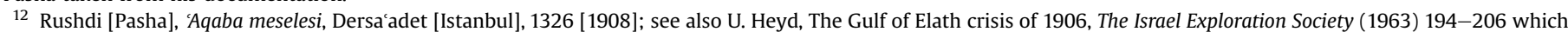
describes the Ottoman perspective on the 'Aqaba incident in 1906 and the way the border was set, including references to material by Rushdi Pasha.

13 G. Biger, Mohammed Ali's firman and the map of 1841, Middle Eastern Studies 14 (1978) 323-325.

14 Biger, Mohammed Ali's firman (note 13) 323.

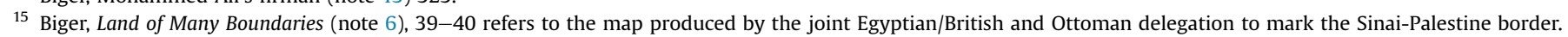


border. During the negotiations they made reference to other potential borders which were all more convenient for them than the Taba-Rafah line suggested by the British (such as the border of the Province of Jerusalem). The British, however, had the upper hand in this affair and their suggested border was accepted, as we know from plenty of British sources.

\section{Ottoman maps of the Sinai-Palestine border}

Eight Ottoman maps of the border area have been located in the Ottoman archives in Istanbul. They are in the digitized map collection which is gradually being opened to researchers (marked in the Ottoman archive as Haritalar). The maps are for the most part written in Ottoman Turkish, although at times they are bilingual and are in Arabic or Ottoman Turkish along with English. In one case the map is in German. It should be noted that since no correspondence accompanies the maps it is at times hard to determine the exact context in which they were produced, or even to date them. Some of them seem to be part of different map series of which we do not possess other elements, but these may be found in the future. It is evident that some of the maps were not originally designed to deal with borders or administrative matters, but that borders were subsequently drawn onto them. Here we present the content of all eight maps, but concentrate on the four most important ones (see Figs. 2-5 and the appendix).

These maps clearly indicate that as far as the Ottoman Empire was concerned the northeastern border of the Province of Egypt was the line defined in the Inheritance Firman of 1841, according to which Muhammad 'Ali and his descendants were to continue ruling Egypt under formal Ottoman sovereignty. Everything in the Sinai beyond this line was still perceived in Ottoman eyes as Ottoman territory. On most maps the administrative borderline of the Province of Egypt went from al-'Arish to Suez (see Fig. 1). ${ }^{16}$

Some Ottoman maps from the mid-nineteenth century, before the British occupation of Egypt, mark the Sinai as belonging to the Province of Hijjaz, which also included the southern part of Ottoman Palestine up to a line between the Dead Sea and Rafah, including access to the Mediterranean Sea (see Fig. 1). ${ }^{17}$ Later maps include parts of Sinai in the Province of Syria (see Fig. 2) or the Province of Jerusalem. The map in Fig. 3, for instance, while indicating the British/Egyptian demands in the negotiations in 1906, shows that the Ottomans adhered to the Inheritance Firman which left Sinai in their hands. In addition, as another way to oppose the 'Aqaba to Rafah line proposed by the British they clearly emphasized the administrative borders of the Province of Jerusalem as including large segments of central Sinai. The southern border of this province is marked in a yellow dashed line going from Rafah to central Sinai (where it almost meets the Inheritance Firman line) and from there to Taba (see Fig. 3). Another map in the set which deals with the changing borders of Egypt shows that a short-lived offer by the European Empires and the Ottomans to Muhammad 'Ali to solve the Egyptian crisis during the London Conference in July 1840 - a proposal that he rejected out of hand - was to include the Sinai and
Ottoman Palestine in the Province of Acre. Had Muhammad 'Ali accepted this offer, these territories would have been administered by the Egyptian ruler but under Ottoman sovereignty. ${ }^{18}$

Even though the Ottomans acknowledged only the line drawn in the Inheritance Firman of 1841 as the northeastern border of the Province of Egypt, and saw the bulk of the Sinai desert as a region under their full control, two maps illustrate the problematic nature of their actual sovereignty on the ground in all or parts of the Sinai desert. One of the maps, from the end of the nineteenth century, depicts what are called 'foolish Egyptian attempts to establish fortifications along the Red Sea shores', and the Sinai is labeled as under Egyptian control. ${ }^{19}$ Interestingly, the same map designates areas in Arabia which were previously under Ottoman rule as 'areas taken from the justice-pursuing Ottoman Empire.' In addition, in Fig. 2 'Aqaba is called 'Egyptian 'Aqaba,' another indication of the de-facto recognition of the Egyptian presence in this region. On this official map the line of the Inheritance Firman of 1841 does not appear at all. Thus, instead of drawing the border of the Province of Egypt from Suez to al-'Arish on the Mediterranean and leaving control over the Sinai in Ottoman hands, in this map the Sinai Peninsula (other than the triangle which belongs to the Province of Syria and extends to Qal'at al-Nakhl) is included within the borders of the Province of Egypt. Ignoring the lines of the Inheritance Firman of 1841 may thus reflect the situation on the ground in Sinai as it developed after 1841. This was de-facto control by the Egyptian house of Muhammad 'Ali over the Sinai, Egyptian guarding of the pilgrimage route through this desert, and even a permanent Egyptian presence in 'Aqaba in the Province of Hijjaz. Officially, Egyptian forces were only allowed by the Ottomans to enter the Sinai to secure the Hajj caravans. ${ }^{20} \mathrm{~A}$ problem arose when the Egyptian forces tried to establish themselves there permanently and even crossed to the Hijjaz. No wonder that on the map in Fig. 3, which shows the proposals for borders between British-ruled Egypt and Ottoman Palestine around 1906, the Ottomans insisted on an annotation on the map that the Sinai had only been given to the khedivate of Egypt as a temporary holding and not as a legitimate permanent possession. Thus, again, as far as the Ottomans were concerned, when they negotiated the border with the British in 1906, the Sinai fully belonged to them.

Another key aspect of these Ottoman maps is that the southern border of Ottoman Palestine varies considerably from map to map: from Gaza to the Dead Sea, al-'Arish to the central Negev and from there to the Dead Sea, Rafah to the Central Negev and from there to the Southern Dead Sea, Khan-Yunes to Qal'at al-Nakhl in central Sinai and from there to the 'Arava valley (see Fig. 2), or even Rafah to the 1841 Inheritance Firman line and from there towards the Gulf of 'Aqaba (see Fig. 3). ${ }^{21}$ One map that deals with the changing borders of Egypt in the nineteenth century reflects a proposal that never materialized, and shows the Sinai and Ottoman Palestine as a single entity. ${ }^{22}$

Nevertheless, out of all these borders - which together illustrate the fluidity of the Ottoman understanding of what a 'border' might

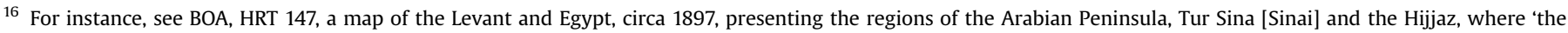
Egyptians made foolish attempts to build fortifications in the Gulf of Sharem [Ras Nazrani] on the shores of the Red Sea upon the death of Ibn al-Rashid'.

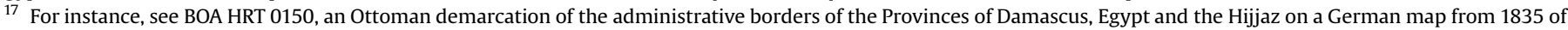

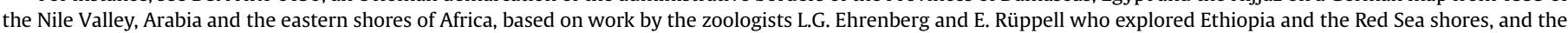
travels of Carsten Niebuhr.

18 BOA HRT 0656, a map dated hijjri year 1335 [1917] showing the changes to the borders of Ottoman Egypt during the nineteenth century.

19 BOA HRT 0147.

20 Brawer, Israel's Boundaries (note 5), 61.

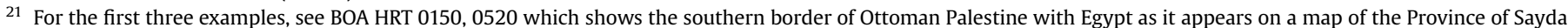
in the year 1265 hijjri [1849], and 0147.

22 BOA HRT 0656.
} 


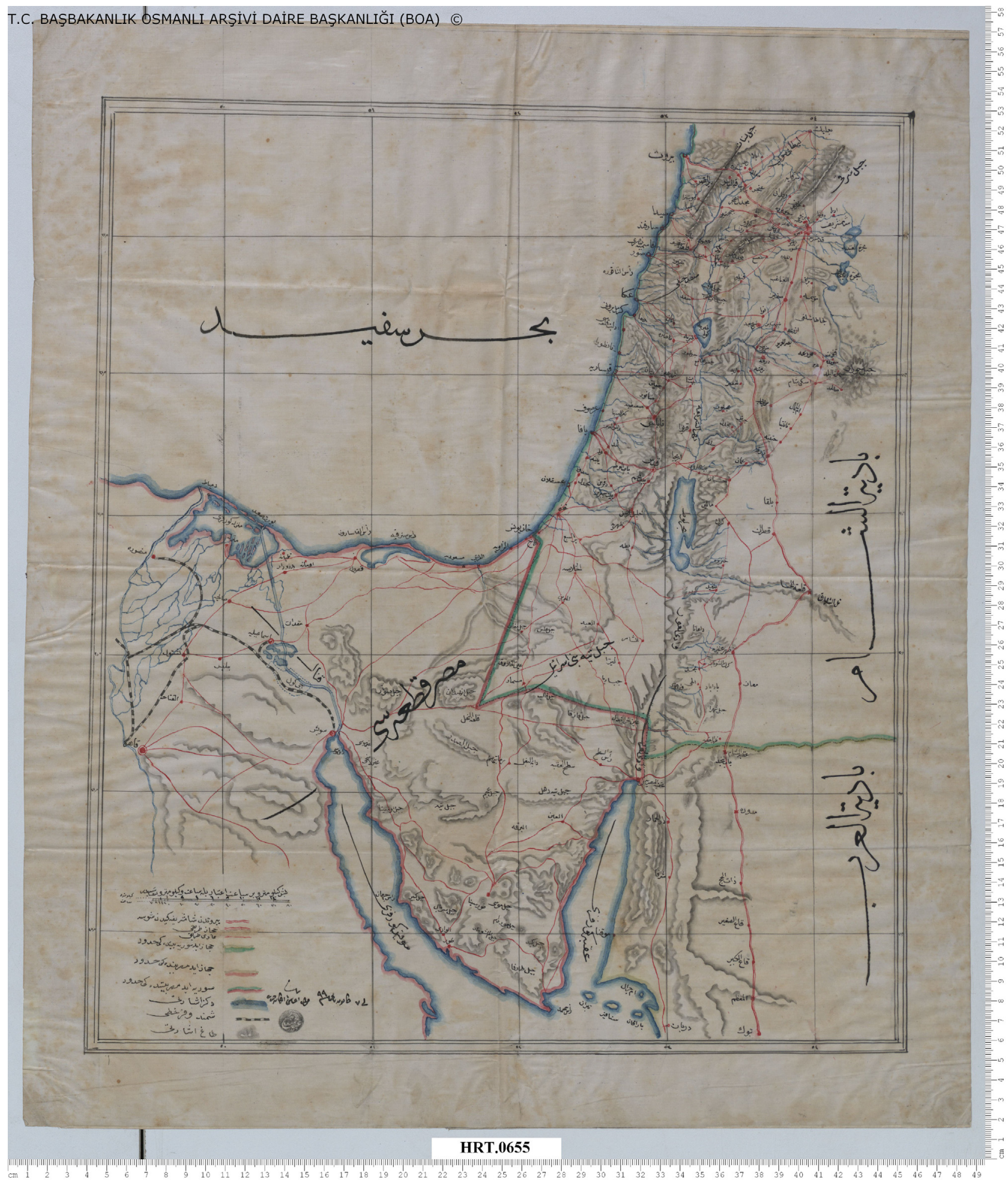

Fig. 2. The Border of Ottoman Palestine and Egypt on a map from the year 1299 of the Mali Calendar [1884]. Source: BOA. HRT. 0655

be - there is no line that resembles the one that was eventually drawn in 1906 during the negotiations with the British. For the Ottomans, this was a line with no historical precedent that the British were forcing them to accept. As a result, there were differences of opinion between the two sides during the negotiations concerning the demarcation of the actual border. The Ottoman representatives suggested a line that penetrated deep into the Sinai and left part of the peninsula, particularly the important water sources along the Rafah to 'Aqaba route, including the road itself, in Ottoman hands (see Fig. 3). This line was already a concession from the Ottoman standpoint since it was far removed from the border of the District of Jerusalem as the Ottomans had drawn it (see Figs. 2 


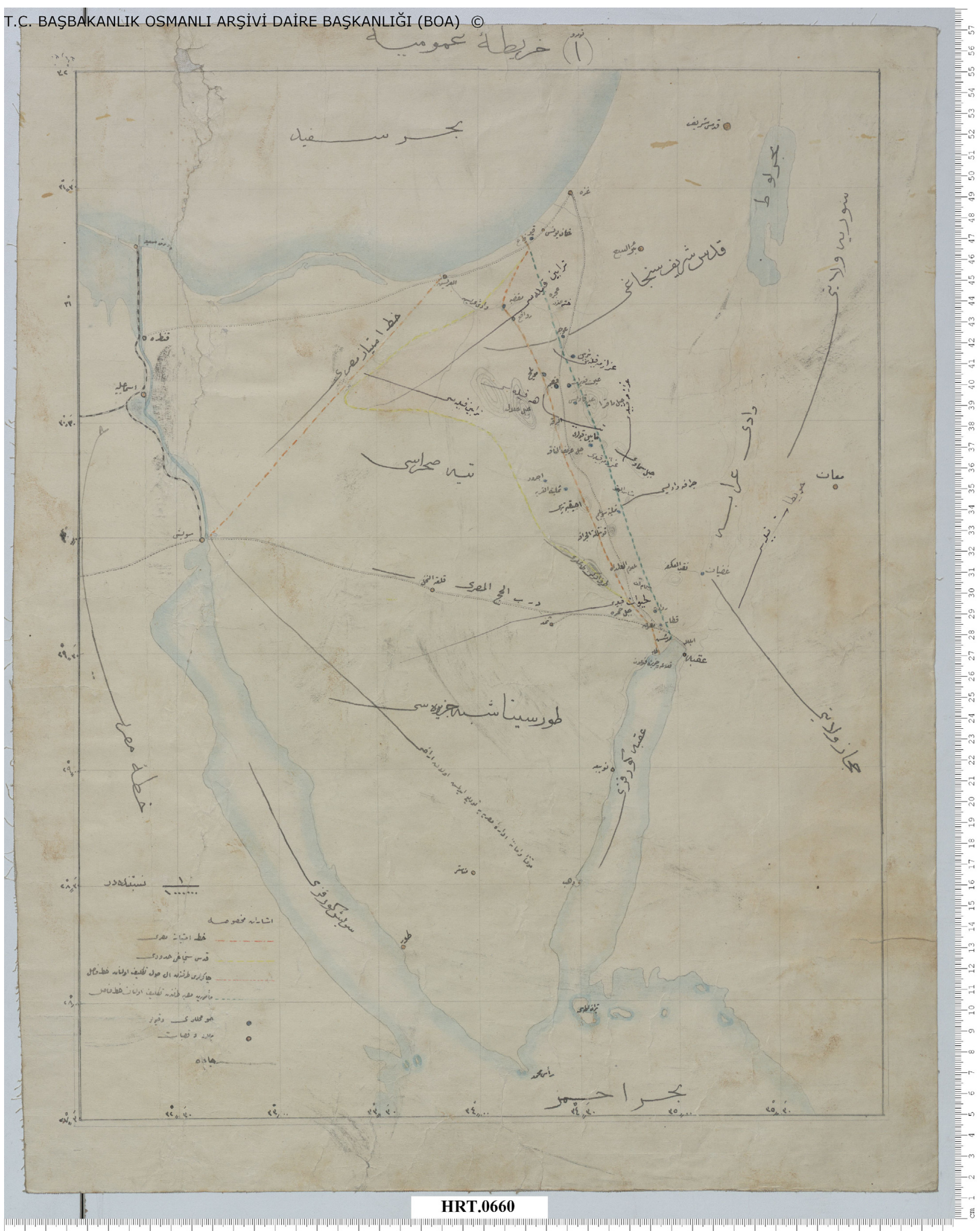

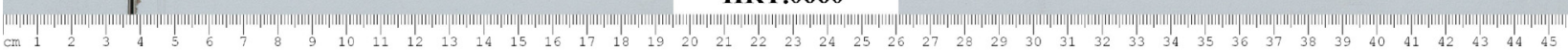

Fig. 3. The Border region between Ottoman Palestine and Egypt in 1906. Source: BOA. HRT. 0660 


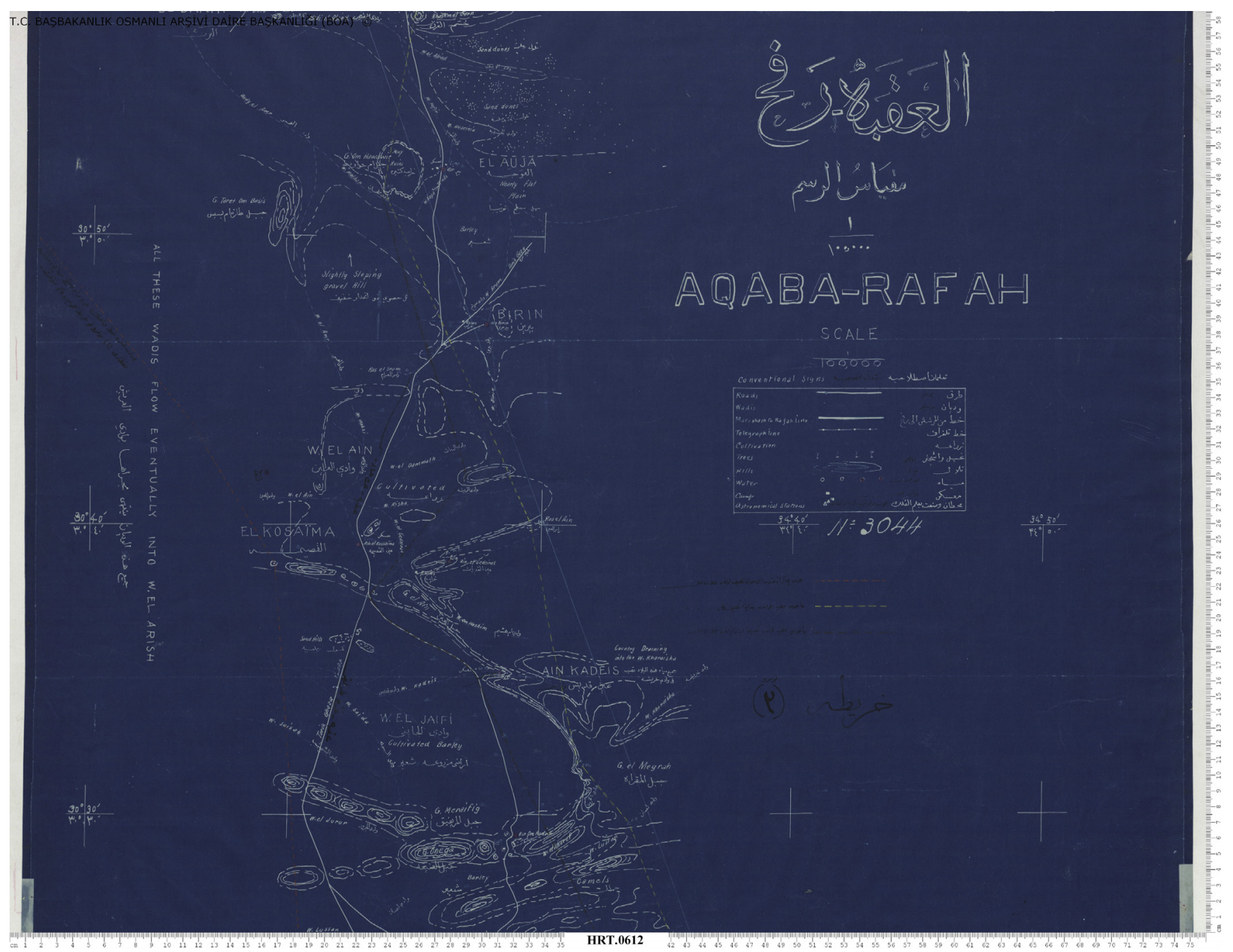

Fig. 4. Part of a series of five blueprint maps depicting the border region between Ottoman Palestine and Egypt dated 1906 . Source: BOA. HRT. 0612

and 3), not to mention the line of the Inheritance Firman, which was their starting point. The Egyptian officials, who in fact worked for the British, suggested a line that was very similar to what was eventually decided upon in 1906 (see Fig. 3). Another map shows that there were at least three lines that the parties were considering (see Fig. 4): the line suggested by the Ottomans which left parts of the Sinai in their hands; the line suggested by the Egyptian officials; and a different adjusted line also proposed by the Egyptians. Hence there was bargaining between the sides, and the line that was eventually approved did not match any of the proposals, although it was much closer to the Egyptian/British position than the Ottoman one.

Overall, the maps confirm the view from the literature that when the British and the Ottomans wanted to delineate the border between the Sinai and Ottoman Palestine, the Ottoman side found it very hard to produce reliable maps of the region and lacked reliable information about the border region, except for the crucial and wellstudied head of the Gulf of 'Aqaba. ${ }^{23}$ The map in Fig. 4, an official Ottoman map which is one of a series of five written in Arabic and
English that covers the entire Sinai-Palestine border from 'Aqaba to Rafah, is the best testimony to the Ottoman difficulty in producing reliable maps of the border region. The handwritten notes in Ottoman Turkish on the original English/Arabic map suggest that this was probably a working draft that the Ottoman side used during meetings of the joint British-Ottoman delegation which worked for forty days in the border region itself in the summer of 1906, after the political decision about the borderline had already been made, marking the line on the ground with wooden poles that were later replaced by piles of stones. ${ }^{24}$ These five maps provide the best and most accurate geographical description of the border region from this period available today. They demonstrate how the Ottoman conception of the status of the Sinai as still being part of their imperial domains differed from the British one during the negotiations in 1906. Hence, despite discussing the new Rafah to 'Aqaba (in fact Taba) border suggested by the British, as marked on the map, the Ottoman officials still made reference to several other lines which were all more convenient for them. The latter included the border of the Province of Jerusalem which went deep into Sinai, the line where

\footnotetext{
23 See the map in Rushdi [Pasha], 'Aqaba meselesi (note 12); see also Fig. 5.

24 Rushdi [Pasha], 'Aqaba meselesi (note 12), 69-72.
} 


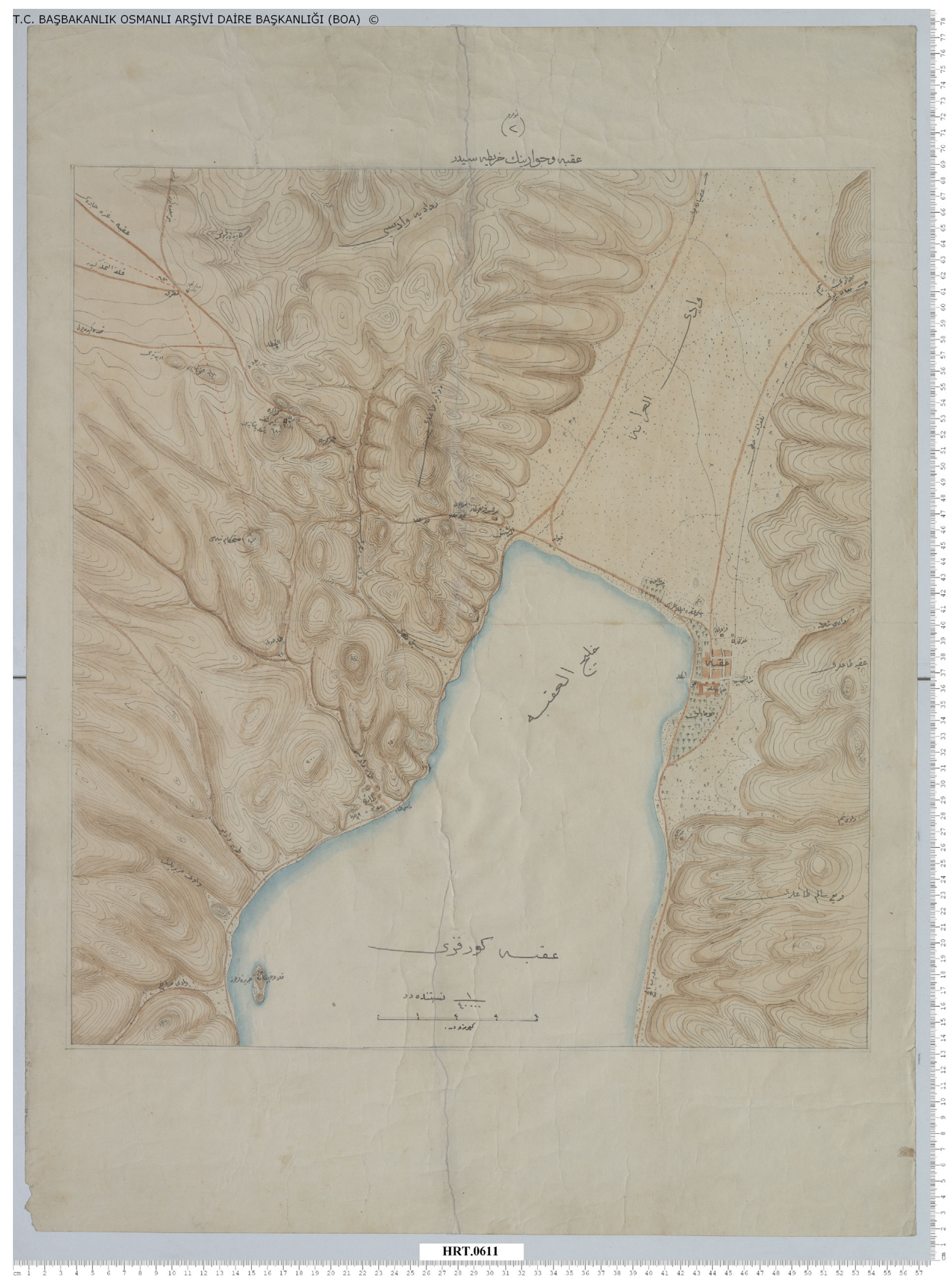

Fig. 5. The head of the Gulf of 'Aqaba and the border between Ottoman Palestine and Egypt. Source: BOA. HRT. 0611 
the Ottoman officials wanted to place the border during its marking, and the line initially proposed by the Egyptians (see details of Fig. 4 in the Appendix). The fact that the Ottomans had to use this map shows once more that they lacked credible, reliable maps of their own of this region at the time. Concomitantly, it shows that they did not hesitate to use European maps for their purposes, when this served their interests. The literature amply illustrates this characteristic of Ottoman cartography from its very early stages; namely, the ability (and need) to borrow mapping techniques and knowledge from other cultures. ${ }^{25}$

Detailed Ottoman maps of the border region were probably only produced after the final border was set, as shown in Fig. 5. This map is a detailed Ottoman map of the region east of the head of the Gulf of 'Aqaba which, according to its numbering, is part of a larger series of maps (currently not available in the Ottoman archives). This map is very different from the other maps discussed here and represents a new phase in Ottoman mapping. It is very precise and accurate compared to previous maps, includes topographic data, heights and various topographic features. We know it was drawn after 1906 since the border between Sinai and Palestine is already marked. ${ }^{26}$ This map is thus the first 'modern' Ottoman map of the Sinai-Palestine border we have been able to locate.

Overall, the maps surveyed here indicate the extent to which the Ottoman perception of the status of the Sinai was different from the British one, and shed light on the Ottoman predicament during the negotiations engendered by their poor cartographical skills and inability to produce accurate maps of the border region. This, however, does not mean that accurate maps would have changed the end result.

\section{Conclusion}

To date, most research on the historical geography of the border between Ottoman Palestine and Egypt has been based on British documents and maps, with almost no reference to Ottoman sources. This article highlights the opportunities provided by Ottoman sources now available to researchers to achieve a more balanced and nuanced picture of these border negotiations. Taken together, the newly discovered Ottoman maps presented here provide a clearer view of the Ottoman perception of the border between Sinai and Palestine, which differs from the better-known British perspective.

The Ottoman maps confirm that before the 1910s the Ottomans lacked the ability to map the border with British-ruled Egypt in a professional, modern way and had to revert to British maps for knowledge of the region. Such borrowed maps were adjusted to fit Ottoman needs and ideology. Only one of the maps surveyed here, which was probably drafted sometime in the 1910s (Fig. 5), clearly illustrates the development of Ottoman mapping capability during the Empire's final period. This coincides with what we know about the concentrated effort to systematically map the Empire's territory after the Young Turk Revolution of 1908. Prior to this time there were many Ottoman maps of various kinds which were not drawn in a systematic and unified way, or using modern cartographical methods. This situation hindered the Ottomans when, in 1906, they came to negotiate the border with the British in this strategically important region. The line eventually drawn in 1906 was very similar to the line the British promoted and very different from what (and where) the Ottomans wanted it to be, although given the British-Ottoman balance of power at the time one cannot really assume that better Ottoman cartographic abilities would have led to a different final outcome. What they do clearly show is the scale of the Ottoman defeat given what they understood as their sovereignty in the Sinai.

More generally, the Ottoman maps presented here indicate the extent to which the issue of borders in the Ottoman Empire at the time was fluid and not fixed. There was no official, definitive and exact map that marked the border of Egypt and Palestine. The Ottomans apparently refused to acknowledge developments taking place on the ground and kept on treating territories long under foreign control as though they were still parts of their domain. ${ }^{27}$ This ideological approach appears in the notations added to maps which defined the enemy in a derogatory way (such as 'foolish Egyptian attempts'), and presented the Empire in a completely different light ('areas taken from the justice-pursuing Ottoman Empire').

Finally, the maps presented here were not used during the Israeli-Egyptian negotiations on the border between the two states from the late 1970s to the mid 1980s. Although it is not clear at all whether they would have made a difference, one can only speculate how different the Israeli-Egyptian border negotiations, which were mainly based on British sources, might have been if some of the Ottoman maps had been known at the time, or if the general Ottoman point of view had been taken into account. At any rate, after years of writing histories (and setting borders) in the Middle East with little attention to sources and people from the region, it is worthwhile examining how these borders were imagined and drawn by the major Islamic power at the time. Clearly, the Ottoman conception of the status of the Sinai, as seen in these maps, was different from the British one, a fact which deserves our attention, even if the Ottomans did not have enough political capital and ability at the time to change the delineation of the border drawn under British pressure between the Sinai and Palestine.

\section{Acknowledgments}

We would like to thank Prof. Gideon Biger for reading and commenting on an earlier version of this article. We would also like to thank Orit Ben-Artzi for preparing the map in Fig. 1. Finally, we would like to thank the three anonymous referees for their thoughtful comments and the editor Prof. Miles Ogborn for the way in which he handled our paper and for all his insights and suggestions.

\section{Appendix}

\section{Details of Figure 2}

Map Title and Characteristics:

Title is missing in the original. Map of the administrative borders delineating the Ottoman provinces of Egypt, Syria and the Hijjaz.

Year:

7 Kanunusani 1299 [19 January 1884]

\section{Cartographer:}

'Your [the Sultan's] servant who works in the Ministry of War', seal added of a person named 'Abd al-Hamid. ${ }^{28}$

\footnotetext{
25 Fortna, Imperial Classroom (note 3), 172-174.

26 See Müdürlügü, Haritacı Mehmet Șevki Pașa.

27 Fortna, Imperial Classroom (note 3), 190-199.

28 For more on the critical role of the Ministry of War in the development of Ottoman mapping, see Fortna, Imperial Classroom (note 3 ), $166,173$.
} 
Printing House:

Not mentioned

Scale:

Is given in both kilometers as well as in hours by horseback; the calculation is five kilometres for one hour on horseback [the map editor erred here, and the time and distances lines should be reversed].

Black and White/Colour:

Colour

Map Legend and Indications:

Double red line, one thick and one thin: major routes, one from Damascus to Beirut and one to the Hijjaz

Single red line: ordinary route

Green line with brown line underneath: border between the Hijjaz and Syria

Brown line with red line underneath: border between the Hijjaz and Egypt

Green line with red line underneath: border between Syria and Egypt

Blue and navy blue lines: sea

Black and white dashed line: railroad

Dark shading: mountains

Description of the Map:

The map shows the borders of the Ottoman Provinces of Egypt, Syria and Hijjaz in 1884. The Province of Syria, which included Ottoman Palestine, goes deep into central Sinai, creating a triangle whose bases are north of the Gulf of 'Aqaba, a point between Rafah and Khan-Yunes and Qal'at al-Nakhl in central Sinai. The Province of Egypt includes the Sinai Peninsula aside from the triangle which belongs to the Province of Syria. Also included in the Province of Egypt is the town of 'Aqaba which is called 'Egyptian 'Aqaba', the southern 'Arava valley, and the Mediterranean shore up to a point between Rafah and Khan-Yunes. The Province of Hijjaz does not penetrate into the Sinai as in other maps, but rather includes the eastern shores of the Red-Sea, up to a point northeast of the town of 'Aqaba. The point where the three provinces intersect is located in the southern 'Arava valley, north of 'Aqaba, near 'Ayn-Kharandal ['Ayn- Gharandal]. ${ }^{29}$

\section{Details of Figure 3}

Map Title and Characteristics:

'General map number 1'. Map of the border region between Ottoman Palestine and Sinai/Egypt in 1906, which was apparently drawn during the negotiations between the Ottomans and the British after the 'Aqaba incident to define the location of the new border between them. The map, which is an official Ottoman map as indicated by the phrase 'the line suggested by your slaves', is one of the most detailed maps available of the border between the Negev and the Sinai in the early twentieth century. It includes 75 names of sites and landscape features, of which 41 are along the border itself. Most of the names are still in use today.

Year:

1906
Cartographer:

Not known

Printing House:

Not mentioned

Scale:

$1: 1,000,000$

Black and White/Colour:

Colour

\section{Map legend and indications:}

Red dotted-dashed line: 'the line of the Egyptian concession' Dashed yellow line: 'border of the Province of Jerusalem' Dashed red line: 'The line suggested by your slaves as the leftmost line' [west]

Dashed green line: 'line proposed by the Egyptian officials'

Shaded blue circles: 'permanent water sources'

Red circle: 'villages and towns'

Solid black line: 'road'

Description of the Map:

There are several lines on the map including the line proposed by the Egyptian officials which is very similar to the line eventually used in 1906 in the agreement between the Ottomans and Britain to separate the Sinai from the Province of Jerusalem (dashed green); the line proposed by the Egyptian officials which went far into the Sinai (dashed orange line); the border of the Egyptian Province as set in the Inheritance Firman given to Muhammad 'Ali in 1841; and the line indicating the District of Jerusalem which went deep into the Sinai (dashed yellow line).

\section{Details of Figure 4}

Map Title and Characteristics:

"Aqaba to Rafah' (map 2 of 5). The Arabic reads: 'Committee for the Drawing of the Borders in the region of 'Aqaba-Rafah, 1906'. This is a blueprint of a dual Arabic/English map, with later annotations in Ottoman. The map was apparently produced by the British as part of their preparations to mark the exact borderline on the ground. ${ }^{30}$

Year:

1906

\section{Cartographer:}

Not known

Printing House:

Not known

Scale:

$1: 100,000$

Black and White/Colour:

Blueprint map

Map Legend and Indications:

The legend includes the following indications: roads, wadis, the road between Rafah and Marashash [Umm Rashrash, Eilat],

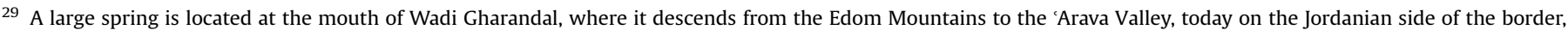
some 100 kilometers from the Gulf of 'Aqaba. Remains of a Roman fortress and an ancient road from 'Aqaba to Petra were discovered nearby.

30 Brawer, Israel's Boundaries (note 5), 67.
} 
telegraph line, cultivated land, trees [in Arabic, 'dates and trees'], hills, water sources and camps.

The Ottoman side added three lines below the original table:

Dashed red line: 'the leftmost [western] line proposed by your [the Sultan's] loyal slaves'

Dashed yellow line: 'the separation line proposed by the Egyptian officials initially [at the beginning of negotiations]'

Dashed brown line: 'the rectified separation line proposed by the Egyptian officials'

Description of the Map:

This Ottoman official series has five parts, all of which are available today, along the 'Aqaba to Rafah road.

\section{Details of Figure 5}

Map Title and Characteristics:

An Ottoman official map of the head of the Gulf of 'Aqaba, which is part of a larger series of maps we do not currently possess (this is Map 2 in the series).

Year:

Not known, not before 1906
Cartographer:

Not known

Printing House:

Not mentioned

Scale:

$1: 40,000$

Black and White/Colour:

Colour

Map Legend and Indicators:

Not provided on this specific sheet

Description of the Map:

Topographic map of the head of the Gulf of 'Aqaba. The border between the Sinai and the Negev is marked on this map by a broken red line which starts at Ras-Taba on the shore of the Red Sea and goes toward the northwest. Along the borderline topographic features are designated which at times have names, as well as permanent and temporary military outposts, water sources, the names of the major wadis, and detailed information on the town of 'Aqaba. 